\title{
PERTUMBUHAN DAN HASIL TIGA VARIETAS CABAI MERAH (Capsicum annuum L.) DENGAN APLIKASI KALIUM SULFAT
}

\section{Growth and Yield Three Varieties of Red Chili (Capsicum annuum L.) By Application Potassium Sulfate $\left(\mathrm{K}_{2} \mathrm{SO}_{4}\right)$}

\author{
Muhammad Alqamari ${ }^{1}$, Chairani Hanum², Hamidah Hanum² \\ ${ }^{1}$ Program Studi Agroekoteknologi, Fakultas Pertanian,Universitas Muhammadiyah Sumatera Utara \\ ${ }^{2}$ Program studi Agroekoteknologi, Fakultas Pertanian Universitas Sumatera Utara \\ *Corresponding author: alqomari484@gmail.com
}

\begin{abstract}
This research was conducted in the experimental field of Agricultural Faculty of North Sumatra Muhammadiyah University with a height of \pm 27 meters dpl, held in july - nov 2012. This study aims to determine the best dose frequency of k2so4 on growth and the result of red chili varieties. This research was conducted using the split plot design with two factors; the varieties factor as the main plot with 3 kinds of varieties, named, $\mathrm{V}_{1}=\mathrm{TM} 999, \mathrm{~V}_{2}=$ Lado, $\mathrm{V}_{3}=$ Landung; and the dose and frequency factors of $\mathrm{k} 2 \mathrm{so} 4$ as subplot with 10 stages of treatment which is: $\mathrm{K} 0=0$, dose $=1.5 \mathrm{~g} /$ liter frequency $6 \times(\mathrm{K} 1), 9 \times(\mathrm{K} 2)$ and $12 \times(\mathrm{K} 3)$, dose $=3$ grams / liter frequency $6 \times(\mathrm{K} 4), 9 \times(\mathrm{K} 5)$ and $12 \times(\mathrm{K} 6)$, dose $=4.5 \mathrm{~g} /$ liter frequency $6 \times(\mathrm{K} 7), 9 \times(\mathrm{K} 8)$ and $12 \times(\mathrm{K} 9)$. The fertilizing was cunducted in the morning at $06.30 \mathrm{am}-08.30 \mathrm{am}$. The measured variables are plant height, numbers of chlorophyll, age of flower, numbers of flower, the percentage of deciduous fruit, weight of fruit/plot. Varieties show significant differences in plant height, numbers of chlorophyll leaf, age of flower, numbers of flower, the percentage of deciduous fruit, numbers of fruit, weight of fruit, weight of fruit per plot, moisture content and storability. Dose and frequency treatment of potassium sulfate is significantly different from controls. The best dose and frequency of this research is K9 which is $4.5 \mathrm{~g} /$ liter k2so4 with 12 time frequency during the growing season in TM 999 and Landung while the varieties of Lado are at dose of $3 \mathrm{~g} /$ liter of water with 12 times in giving (K5).
\end{abstract}

Keywords: potassium, $\mathrm{K}_{2} \mathrm{SO}_{4}$, varieties, Capcicum annum

\section{ABSTRAK}

Penelitian ini dilaksanakan di lahan percobaan Fakultas Pertanian Universitas Muhammadiyah Sumatera Utara dengan ketinggian \pm 27 meter dari permukaan laut dilaksanakan pada bulan Juli sampai dengan November 2012. Penelitian ini bertujuan untuk menentukan dosis dan frekuensi dari $\mathrm{K}_{2} \mathrm{SO}_{4}$ yang terbaik terhadap pertumbuhan dan hasil varietas cabai merah. Penelitian ini dilakukan dengan menggunakan Rancangan Petak Terbagi (RPT) dengan 2 faktor yaitu : Faktor Varietas sebagai petak utama dengan 3 (tiga) macam varietas yaitu : $V=T M 999, V_{2}=$ Lado $V_{3}=$ Landung dan faktor dosis dan frekuensi $\mathrm{K}_{2} \mathrm{SO}_{4}$ sebagai anak petak dengan 10 taraf perlakuan yaitu : $\mathrm{K}_{0}=0$, dosis = 1,5 gr/liter frekuensi $6 \times\left(\mathrm{K}_{1}\right), 9 \times\left(\mathrm{K}_{2}\right)$ dan $12 \times\left(\mathrm{K}_{3}\right)$, dosis $=3 \mathrm{gr} /$ liter frekuensi $6 \times\left(\mathrm{K}_{4}\right)$, $9 \times\left(\mathrm{K}_{5}\right)$ dan $12 \times\left(\mathrm{K}_{6}\right)$, dosis = 4,5 gr/liter frekuensi $6 \times\left(\mathrm{K}_{7}\right), 9 \times\left(\mathrm{K}_{8}\right)$ dan $12 \times\left(\mathrm{K}_{9}\right)$ aplikasi pemupukan dilakaukan pada pagi hari dari pukul 06-30 sampai 08-30 wib. Peubah yang diamati : tinggi tanaman, jumlah klorofil daun, umur berbunga, Jumlah bunga, persentase buah gugur, berat buah/plot. Varietas menunjukkan perbedaan nyata pada tinggi tanaman, jumlah klorofil daun, umur berbunga, Jumlah bunga, persentase buah gugur, jumlah buah, berat buah pertanaman, berat buah perplot, kadar air dan daya simpan. Perlakuan dosis dan frekuensi pupuk kalium sulfat berbeda nyata dengan kontrol. Dosis dan frekuensi terbaik dari penelitian ini adalah $\mathrm{K}_{9}$ yaitu $4.5 \mathrm{~g} / \mathrm{liter} \mathrm{K}_{2} \mathrm{SO}_{4}$ 
dengan frekuensi 12 kali selama masa tanam pada TM 999 dan Landung, sedangkan varietas Lado pada dosis $3 \mathrm{~g} /$ liter air dengan 12 kali pemberian (K5).

Kata kunci: pupuk kalium, $\mathrm{K}_{2} \mathrm{SO}_{4}$, varietas, Capcicum annum

\section{PENDAHULUAN}

Cabai merah (Capsicum annum) merupakan tanaman hortikultura yang cukup penting di Indonesia dan merupakan salah satu jenis sayuran buah yang mempunyai pontesi untuk dikembangkan karena permintaannya yang tinggi terutama di negara-negara tropis yang dikosumsi dalam keadaan segar maupun kering (Hariyantini dan Santoso, 2001; Sarker dan Fazlur, 2003

Berdasarkan Biro Pusat Statistik (2013), luas panen cabai adalah sebesar 233.904 ha dengan produksi 1.378.727 ton dan produktivitas sebesar 5,89 ton/ha. Produktivitas ini masih jauh dari potensi produktivitas cabai yang dihasilkan dalam berbagai penelitian. Lebih lanjut Deptan (2009) melaporkan bahwa produksi yang dihasilkan juga belum dapat memenuhi kebutuhan konsumsi yang mencapai 2,77 $\mathrm{kg} / \mathrm{kapita} / 2014$. Demi memenuhi keperluan cabai tersebut pemerintah terpaksa mengimport cabai dan produk lainnya seperti bawang merah dan bawang putih dari India.

Salah satu penyebab utama rendahnya produksi cabai dalam negeri adalah rentannya tanaman ini terhadap gugur bunga dan buah sebelum waktunya. Berdasarkan laporan penelitian, hanya 52,6\% keberhasilan bunga menjadi buah dimana dari 500 bunga yang terbentuk hanya 263 bunga yang menjadi buah (Haryantini dan Santoso, 2001; Setiadi, 2005).

Kekurangan unsur kalium pada tanaman jenis Solanaceae akan menghambat pertumbuhan tanaman karena aktivitas enzim di daun rendah sehingga proses fotosintesis dan translokasi hasil fotosintesis menjadi terhambat dan akan mengurangi produksi hasil panen (Perrenoud 1993). Lebih lanjut, Hakim et al. (2008) menyatakan, jika status kalium di dalam tanah tidak mencukupi untuk pertumbuhan maka produksinya akan berkurang.
Disamping kalium, penggunaan sulfur pada tanaman perlu mendapat perhatian, karena sulfur merupakan unsur hara esensial bagi pertumbuhan tanaman. Sulfur memegang peranan penting dalam metabolisme tanaman (Schnug, 1990). Robson dan Pitman (1983) melaporkan, bahwa tanaman yang kekurangan Sulfur dapat mempengaruhi jumlah serapan nitrogen, akibatnya pembentukan protein akan menurun dan juga menurunkan kandungan asam-asam amino cystine, systeine dan methionine.

Marschner (1986) telah melaporkan bahwa sulfur dapat meningkatkan kandungan asam-asam amino systeine dan methionin. Kaunang (2004) menyatakan bahwa pemberian air belerang (sulfur) $50 \%$ memberikan kualitas hijauan Panicum maximum dan Centrosema pubescens yang terbaik.

Berdasarkan uaraian diatas perlu mencari kaedah melalui mekanisme pemberian beberapa Dosis dan frekuensi $\mathrm{K}_{2} \mathrm{SO}_{4}$ yang optimum untuk meningkatkan performa pertumbuhan dan produksi cabai merah

\section{BAHAN DAN METODE}

Penelitian ini dilaksanakan di lahan percobaan UMSU di Jalan Tuar, Kecamatan Medan Amplas dengan ketinggian tempat \pm 27 meter di atas permukaan laut (m dpl). Penelitian ini dilaksanakan pada bulan Juli sampai dengan bulan November 2012.

Bahan-bahan yang digunakan dalam penelitian ini adalah : benih cabai, pupuk kandang sapi, kalsium sulfat, mulsa plastik hitam perak, polybag, bambu, fungsida Dithane M-45 (ba. mancozeb 80\%) dan insektisida Decis 25 EC (ba. deltametrin 25 g/l) dan Confidor 200 SL (ba. imidakloprid $200 \mathrm{~g} / \mathrm{l})$.

Penelitian ini dilakukan dengan menggunakan Rancangan Petak Terbagi 
(RPT) dengan 2 faktor yaitu : Faktor Varietas sebagai petak utama dengan 3 (tiga) macam varietas yaitu : $\mathrm{V}=\mathrm{TM}$ 999, $\mathrm{V}_{2}=$ Lado $\mathrm{V}_{3}=$ Landung dan faktor dosis dan frekuensi $\mathrm{K}_{2} \mathrm{SO}_{4}$ sebagai anak petak dengan 10 taraf perlakuan yaitu : $\mathrm{K}_{0}=0$, dosis $=1,5 \mathrm{gr} /$ liter frekuensi 6 $\mathrm{x}\left(\mathrm{K}_{1}\right), 9 \mathrm{x}\left(\mathrm{K}_{2}\right)$ dan $12 \mathrm{x}\left(\mathrm{K}_{3}\right)$ selama masa tanam, dosis $=3 \mathrm{gr} /$ liter frekuensi $6 \mathrm{x}\left(\mathrm{K}_{4}\right), 9$ $\mathrm{x}\left(\mathrm{K}_{5}\right)$ dan $12 \mathrm{x}\left(\mathrm{K}_{6}\right)$ selama masa tanam, dosis $=4,5 \mathrm{gr} /$ liter frekuensi $6 \times\left(\mathrm{K}_{7}\right), 9 \times\left(\mathrm{K}_{8}\right)$ dan $12 \times\left(\mathrm{K}_{9}\right)$ selama masa tanam.

\section{Pelaksanaan Penelitian}

Lahan penelitian yang digunakan diukur sesuai dengan keperluan dengan ukuran luas lahan 50 x $12 \mathrm{~m}$. Lahan kemudian dibabat, digaru dan dibersihkan dari sisa gulma maupun bebatuan. Selanjutnya pencangkulan dilakukan dengan membalikkan lapisan olah tanah dan menggemburkan tanah dengan tujuan untuk mengeliminasi beberapa jenis hama dan penyakit dan memberi kesempatan tanah untuk beroksidasi sebelum dilakukan pembuatan bedengan untuk plot penelitian.

Pembuatan plot penelitian dilakukan setelah pengolahan tanah. Ukuran plot penelitian yaitu panjang $280 \mathrm{~cm}$ dan lebar 120 $\mathrm{cm}$ dengan jumlah plot 30 plot/ulangan. Jumlah ulangan sebanyak 3 , jarak antar ulangan $100 \mathrm{~cm}$, dan jarak antar plot $50 \mathrm{~cm}$.

Pemasangan mulsa plastik hitam perak (MPHP) dikerjakan setelah pemberian pupuk kandang (500 g/lubang atau 20 ton/ha ) pemberian pupuk kadang diberikan sebelum tanam dengan cara ditebarkan keplot penelitian , penyiraman secukupnya dan pemberian pupuk dasar. Lubang tanam dibuat dengan cara melubangi plastik mulsa menggunakan kaleng bekas susu dengan memasukan arang yang telah dibakar dengan jarak tanam $70 \mathrm{~cm}$ x $50 \mathrm{~cm}$. Fungsi utama MPHP menekan pertumbuhan hama dan gulma, serta mengurangi penguapan air dan pupuk oleh sinar matahari serta menjaga kelembapan, suhu, dan kegemburan tanah.

Penanaman dilakukan setelah bibit berumur 18 hari setelah semai. Bibit yang ditanam terlebih dahulu diseleksi dengan keteria utama adalah keseragaman pertumbuhan baik tinggi maupun jumlah daun.
Pemindahan dilakukan pada sore hari dimulai jam 15.00 WIB untuk menghindari penguapan yang tinggi. Peubah yang diamati : tinggi tanaman, Jumlah bunga, berat buah perplot.

\section{HASIL DAN PEMBAHASAN}

Untuk perlakuan macam varietas, memberikan hasil yang berpengaruh nyata pada parameter saat tinggi tananaman, umur berbunga, jumlah bunga, persentase gugur bunga, jumlah buah dan berat buah perplot. Perlakuan dosis dan frekuensi pupuk $\mathrm{K}_{2} \mathrm{SO}_{4}$, memberikan hasil berpengaruh nyata pada parameter tingi tanaman, jumlah bunga, persentase gugur bunga, jumlah buah dan berat buah perplot dan tidak berpengaruh nyata pada umur berbunga.

\section{A. Pada Fase Vegetatif}

Pengaruh dari Perlakuan tiga Varietas dengan perlakuan Dosis dan frekuensi Pupuk $\mathrm{K}_{2} \mathrm{SO}_{4}$ Terhadap Pertumbuhan Dan Hasil Tanaman Cabai Merah (Capsicum annum L) dapat dilihat pada Tabel 1 .

Penanaman cabai merah berbagai Varietas (V1 = TM 999, V2 = Lado dan V3 = Landung), memberikan pengaruh berbeda sangat nyata pada pertumbuhan cabai merah yang ditunjukkan oleh parameter tinggi tanaman, jumlah clorofil.

Hasil pada tada table 1, menunjukkan tinggi tanaman tertinggi pada V1 $(94,25 \mathrm{~cm})$ berbeda nyata dengan V2 dan V3, sedangkan tinggi tanaman yang terendah pada V3 $(71,81$ $\mathrm{cm})$ berbeda tidak nyata dengan V2 $(75,22$ $\mathrm{cm})$.

Hal ini disebabkan Varietas TM 999 mempunyai keunggulan di banding dengan Varietas Lado dan Landung. Keunggulan dari varietas TM 999 tersebut diantaranya, pertumbuhan tanaman kuat dan tinggi, percabangan banyak. Suatu Varietas didapatkan dari hasil persilangan yang ditujukan untuk mencari keturunan yang berproduksi tinggi, berkualitas dan resisten terhadap hama dan pentakit (Sudjoko Sahat dan Hendro Sunaryono, 1995).

Pada Varietas landung (V3), tinggi tanaman terendah. Hal ini disebabkan 
kemampuan adaptasi dari Varietas tersebut rendah, karena susunan genetis pada Varietas tersebut lingkungan kurang baik. Menurut Apandi (1991), mengatakan pertumbuhan tanaman merupakan perpaduan antara susunan genetis dengan lingkungannya, sehingga respon terhadap lingkungan yang rendah dapat menurunkan pertumbuhan, akibatnya tanaman tersebut tumbuh rendah.

Tabel 1. Rataan tinggi tanaman, jumlah clorofil terhadap varietas cabai merah dengan Aplikasi Kalium Sulfat $\left(\mathrm{K}_{2} \mathrm{SO}_{4}\right)$

\begin{tabular}{|c|c|c|}
\hline \multirow[t]{2}{*}{ Perlakuan } & \multicolumn{2}{|c|}{ Parameter Pengamtan } \\
\hline & Tinggi Tanaman & Jumlah clorofil \\
\hline \multicolumn{3}{|l|}{ Varietas } \\
\hline TM 999 (V1) & $94,25 \mathrm{a}$ & $70.22 b$ \\
\hline Lado (V2) & $75,22 b$ & $70.74 b$ \\
\hline Landung (V3) & $71,81 b$ & $76.90 \mathrm{a}$ \\
\hline \multicolumn{3}{|c|}{ Dosisdan frekuensi $\mathrm{K}_{2} \mathrm{SO}_{4}$} \\
\hline $\mathrm{K}_{0}(0 \mathrm{~g} /$ liter $)$ & $61,36 \mathrm{e}$ & $68.69 \mathrm{~b}$ \\
\hline $\mathrm{K}_{1(1.5 \mathrm{~g} / \text { liter; frekuensi } 6 \text { kali) }}$ & $69,00 \mathrm{~d}$ & $70.93 \mathrm{ab}$ \\
\hline $\mathrm{K}_{2}(1.5 \mathrm{~g} /$ liter; frekuensi 9 kali $)$ & $72,00 \mathrm{~d}$ & $71.73 \mathrm{ab}$ \\
\hline $\mathrm{K}_{3}$ (1.5g/liter; frekuensi 12 kali) & $79,41 \mathrm{c}$ & $72.01 \mathrm{a}$ \\
\hline $\mathrm{K}_{4}$ (3 g/liter; frekuensi $\left.6 \mathrm{kali}\right)$ & $80,11 \mathrm{c}$ & $72.64 \mathrm{a}$ \\
\hline $\mathrm{K}_{5}$ (3 g/liter; frekuensi 9 kali) & $85,22 b$ & $72.86 \mathrm{a}$ \\
\hline $\mathrm{K}_{6}$ (3 g/liter; frekuensi $\left.12 \mathrm{kali}\right)$ & $85,33 b$ & $72.55 \mathrm{a}$ \\
\hline $\mathrm{K}_{7}$ (4.5g/liter; frekuensi 6 kali) & $88,67 b$ & $75.68 \mathrm{a}$ \\
\hline $\mathrm{K}_{8}(4.5 \mathrm{~g} /$ liter; frekuensi 9 kali) & $90,41 \mathrm{a}$ & $73.74 \mathrm{a}$ \\
\hline $\mathrm{K}_{9}(4.5 \mathrm{~g} /$ liter; frekuensi $12 \mathrm{kali})$ & $92,78 \mathrm{a}$ & $75.34 \mathrm{a}$ \\
\hline
\end{tabular}

Jumlah clorofil tertinggi pada V3 (76.90a), berbeda nyata dengan V1 dan berbeda sangat nyata dengan V3. sedangkan jumlah clorofil terendah pada V1 (70.22b), berbeda tidak nyata dengan V2 (70.74b).

Hasil ini menunjukkan bahwa aplikasi pupuk kalium mampu meningkatkan kesuburan tanaman yang ditandai dengan semakin hijaunya daun tanaman cabai. Keberadaan jumlah klorofil yang memadai akan berpengaruh pada produksi tanaman sebagai hasil dari proses fotosintesis. Selain itu unsur kalium juga akan terlibat langsung dalam proses fotosintesis sebagai katalisator dalam tranormasi tepung dan gula menjadi senyawa lain. IIDE (2002) mengemukakan bahwa kalium diperlukan tanaman untuk berbagai fungsi fisiologis termasuk

didalamnya adalah metabilisme karbohidrat, aktifitas enzim, regulasi osmotik, efesiensi penggunaan air, serapan unsur nitrogen, sintesis protein dan translokasi asimilat.

\section{B. Pada Fase Generatif}

Untuk mengetahui pengaruh tiga varietas dengan dosis dan aplikasi pupuk K2SO4 terhadap hasil tanaman cabai merah yang hasilnya disajikan pada Tabel 2 .

Pengamatan terhadap hasil tanaman cabai merah dilakukan pada parameter saat umur berbunga, jumlah bunga, persentase bunga gugur, berat buah per plot. Untuk perlakuan macam varietas, memberikan hasil 
yang berpengaruh pada parameter saat umur berbunga, jumlah bunga, persentase bunga gugur, berat buah per plot menunjukkan hasil sangat berpengaruh nyata. Perlakuan dosis dan frekuensi pupuk $\mathrm{K}_{2} \mathrm{SO}_{4}$, memberikan hasil tidak berpengaruh nyata pada parameter jumlah bunga, persentase bunga gugur, berat buah per plot, dan memberikan hasil berpengaruh tidak nyata pada parameter saat umur berbunga.

Dari Tabel 2 dapat dilihat umur berbuga tercepat terjadi pada perlakuan varietas TM 999 (V1) dengan rata-rata (38.6 hari), yang tidak berbeda pada varitas Lado dengan rata-rata (37.2 hari) sedangkan umur berbunga paling lama yaitu varietas landung (V3) dengan rata-rata (28.7 hari).

Perbedaan umur berbunga ini, berkaitan dengan sifat genetik tanaman. Karena secara umum sifat-sifat seperti umur berbunga dikendalikan oleh gen tunggal yang pengaruh lingkungan sangat rendah dalam hal ekspresi sifat tersebut. Pengaruh lingkungan akan muncul jika tanaman dalam kondisi tercekam sehingga tanaman akan memunculkan bunga lebih awal. Dari data tersebut memperlihatkan umur berbunga tidak berbeda nyata antara pemberian pupuk $\mathrm{K}_{2} \mathrm{SO}_{4}$ dengan yang tidak diberikan akan tetapi pemberian dosis dan frekuensi pupuk $\mathrm{K}_{2} \mathrm{SO}_{4}$ bawah 3 g/liter dengan 9 kali adalah dosis yang paling efektif untuk umur berbunga. Perbedaan umur berbunga terkait dengan fungsi kalium dalam memacu pertumbuhan tanaman. McKenzie (2001) menyatakan bahwa unsur kalaium pada tanaman akan membentu prose fotosintesis dan pemacu pertumbuhan tanaman pada awal pertumbuhan.

Tabel 2. Rataan umur berbunga, jumlah bunga, persentase gugur bunga, berat buah perplot terhadap varietas cabai merah dengan Aplikasi Kalium Sulfat $\left(\mathrm{K}_{2} \mathrm{SO}_{4}\right)$

\begin{tabular}{|c|c|c|c|c|}
\hline \multirow[t]{2}{*}{ Perlakuan } & \multicolumn{4}{|c|}{ Parameter Pengamatan } \\
\hline & $\begin{array}{c}\text { Umur } \\
\text { berbunga }\end{array}$ & $\begin{array}{c}\text { Juamlah } \\
\text { bunga }\end{array}$ & $\begin{array}{c}\% \text { bunga } \\
\text { gugur }\end{array}$ & $\begin{array}{c}\text { Berat buah } \\
\text { perplot }\end{array}$ \\
\hline \multicolumn{5}{|l|}{ Varietas } \\
\hline TM 999 (V1) & $38.6 \mathrm{a}$ & $180 \mathrm{a}$ & $64,74 \mathrm{c}$ & $330, .542 \mathrm{a}$ \\
\hline Lado (V2) & $37.2 \mathrm{a}$ & $172 b$ & $66,53 b$ & $276.179 \mathrm{c}$ \\
\hline Landung (V3) & $28.7 b$ & $162 \mathrm{c}$ & $71,50 \mathrm{a}$ & $291.783 b$ \\
\hline \multicolumn{5}{|c|}{ Dosisdan frekuensi $\mathrm{K}_{2} \mathrm{SO}_{4}$} \\
\hline $\mathrm{K}_{0(0 \mathrm{~g} / \mathrm{liter})}$ & $37.2 \mathrm{a}$ & $154 \mathrm{e}$ & $71,23 \mathrm{a}$ & $62.7722 \mathrm{e}$ \\
\hline $\mathrm{K}_{1 \text { (1.5g/liter; frekuensi } 6 \mathrm{kali})}$ & $36.2 \mathrm{a}$ & $165 d$ & $70,51 \mathrm{a}$ & $99.5456 \mathrm{e}$ \\
\hline $\mathrm{K}_{2}(1.5 \mathrm{~g} /$ liter; frekuensi 9 kali $)$ & $35.6 a$ & 166d & $69,22 \mathrm{a}$ & $135.572 \mathrm{de}$ \\
\hline $\mathrm{K}_{3(1.5 \mathrm{~g} / \text { liter; frekuensi } 12 \mathrm{kali})}$ & $35.3 \mathrm{a}$ & $170 \mathrm{c}$ & $68,06 \mathrm{a}$ & $199.324 d$ \\
\hline $\mathrm{K}_{4 \text { (3 g/liter; frekuensi } 6 \text { kali) }}$ & $35.2 \mathrm{a}$ & $173 b$ & $68,47 \mathrm{a}$ & $303.614 c$ \\
\hline $\mathrm{K}_{5}$ (3 g/liter; frekuensi 9 kali) & $34.4 \mathrm{a}$ & $174 b$ & $67,85 \mathrm{a}$ & $316.988 \mathrm{c}$ \\
\hline $\mathrm{K}_{6}(3 \mathrm{~g} /$ liter; frekuensi 12 kali $)$ & $33.9 \mathrm{a}$ & $178 \mathrm{a}$ & $66,58 b$ & $407.788 b$ \\
\hline $\mathrm{K}_{7}$ (4.5g/liter; frekuensi 6 kali) & $33.7 \mathrm{a}$ & $182 \mathrm{a}$ & $66,57 b$ & $444.087 b$ \\
\hline $\mathrm{K}_{8}$ (4.5g/liter; frekuensi $\left.9 \mathrm{kali}\right)$ & $33.7 \mathrm{a}$ & $180 \mathrm{a}$ & $66,26 b$ & $512.709 a$ \\
\hline $\mathrm{K}_{9}(4.5 \mathrm{~g} /$ liter; frekuensi $12 \mathrm{kali})$ & $32.9 b$ & $173 b$ & $61,15 c$ & $512.611 \mathrm{a}$ \\
\hline
\end{tabular}

Keterangan: Angka yang diikuti huruf yang sama pada kolom yang sama tidak berbeda nyata pada uji DMRT dengan taraf 0.05 .

Persentase gugur bunga terendah terdapat pada varietas TM 999 dengan rataan $64.74 \%$ yang berbeda dengan varietas lainnya dan yang terendah terdapat pada varietas Landung dengan rataan $71.50 \%$. Tabel 2 juga menunjukkan bahwa perlakuan dosis dan frekuensi $\mathrm{K}_{2} \mathrm{SO}_{4}$ baru menunjukkan pengaruh yang nyata pada dosis $3 \mathrm{~g} / \mathrm{liter}$ dengan frekuensi 12 kali. Hal ini menunjukkan perlakuan dengan aplikasi $\mathrm{K}_{2} \mathrm{SO}_{4}$ pada dosis tertinggi 
menunjukkan penurunan jumlah gugur bunga. Rendahnya gugur bunga dalam hal ini disebabkan unsur hara yang diserap oleh tanaman tercukupi, sehingga hasil fotosintesis yang dihasilkan dapat mempengaruhi persentase gugur bunga. Menurut (Hardjowigeno, 1995). Tanaman yang kekurangan unsur $\mathrm{K}$, bunga dan buah mudah gugur serta aktivitas fotosintesis terhambat. Djoko, Isbandi, (1986) juga menyatakan bahwa penambahan pupuk $\mathrm{K}_{2} \mathrm{SO}_{4}$ akan mempengaruhi ketersediaan dan laju serapan unsur hara oleh tanaman. Besarnya ketersediaan unsur hara dalam tanah sangat mempengaruhi pembungaan pada tanaman.

Berat buah perplot tertinggi terdapat pada varietas TM 999 , berat buah tertinggi yaitu 330,.542a g, Setiap varietas mempunyai adaptasi yang berbeda-beda terhadap lingkungannya. Setiap varietas memiliki susunan genetik yang berbeda, yang masing-masing susunan genetik mempunyai kemampuan tertentu untuk beradaptasi dengan lingkungan tempat tumbuhnya. Penggunaan varietas yang unggul, akan menyebabkan varietas tersebut tinggi kemampuannya dalam menyerap unsur hara. Hal ini menyebabkan tanaman tumbuh baik. Selain itu juga menurut Apandi (1991).

Hasil pada tabel 2 menunjukkan bahwa aplikasi pupuk $\mathrm{K}_{2} \mathrm{SO}_{4}$ dapat meningkatkan bobot buah per plot sejalan dengan peningkatan dosis dan frekuensi aplikasi. Pada varietas TM 999 (V1) menghasilkan berat buah perplot tertinggi. Hal ini menunjukkan pada akhir panen respon tanaman terhadap pupuk $\mathrm{K}_{2} \mathrm{SO}_{4}$ masih ada. Sehingga mempengaruhi berat buah per plot. Kemampuan adaptasi tanaman, terlihat saat tanaman memberikan respon terhadap unsur hara yang tersedia yang ditunjukkan oleh rendahnya produksi dari tanaman kontrol. Hal ini disebabkan karena unsur hara merupakan faktor yang sangat dibutuhkan tanaman dalam proses pertumbuhan dan perkembangan tanaman (Sosroedirdjo dkk, 1990).

Pemberian pupuk $\mathrm{K}_{2} \mathrm{SO}_{4}$ dengan dosis dan aplikasi tertinggi (K9) mampu meningkatkan bobot buah per plot, hal ini disebabkan karena tersedianya unsur hara bagi tanamanyaituunsur hara Kalium dan Sulfur, dimana unsur hara ini merupakan unsur hara esensial yang dibutuhkan tanaman dalam jumlah yang besar, sehingga dengan adanya pemupukan $\mathrm{K}_{2} \mathrm{SO}_{4} \quad$ mampu meningkatkan berat buah per plot, menurut Suprapto (1993), pemupukan memegang peranan penting dalam meningkatkan produksi cabai merah, karena pupuk mengandung unsur hara yang relatif tinggi.

Tanpa pemberian pupuk $\mathrm{K}_{2} \mathrm{SO}_{4}$ (K0) menghasilkan jumlah buah yang terendah, hal ini disebabkan tanaman cabai merah hanya mengandalkan unsur hara yang tersedia dari tanah saja, sehingga pembentukan buah buah kurang baik. Tanaman yang kekurangan unsur N, P dan K hasil berupa buah akan merosot (Sumardi dan Suriatna, 1993).

\section{KESIMPULAN DAN SARAN}

Dari hasil penelitian yang berjudul Pertumbuhan Dan Hasil Tiga Varietas Cabai Merah (Capsicum Annuum L.) Dengan Aplikasi Kalium Sulfat dapat disimpulkan bahwa:

1. Penggunaan macam varietas menunjukkan berpengaruh sangat nyata terhadap tinggi tanaman, Jumlah clorfil, umur berbunga, junlah bunga, persentase gugur bunga, jumlah buah merah per plot.

2. Perlakuan dosis dan frekunsi pupuk $\mathrm{K}_{2} \mathrm{SO}_{4}$ berpengaruh nyata pada tinggi tanaman, jumlah clorofil , saat berbunga, jumlah bunga, persentase 
bunga gugur, berat buah merah per plot terhadap kontrol.

3. TM 999 merupakan varietas terbaik pada variabel tinggi tanaman, jumlah bunga,persentasi bunga gugur, jumlah buahdan jumlah buah perplot. Kesentrasi dan frekuesi $\mathrm{K}_{2} \mathrm{SO}_{4}$ pada pemberian 4,5 gr/liter, frekuensi $12 \mathrm{x}$ selamamasa tanam mampu meningkatkan jumlah bunga,persentasi bunga gugur, jumlah buah, jumlah buah perplot, daya simpan dan kandungan capsaicin.

\section{DAFTAR PUSTAKA}

Apandi.M, 1984.Teknologi Buah dan Sayur.Alumni Bandung.

BPS.2013.http://www.bps.go.id/hasil_p ublikasi/SI_2013/index3.php?pu $\mathrm{b}=$ Statistik+Indonesia +2013

[Deptan] Departemen Pertanian, 2009. Konsumsi perkapita sayuran di Indonesia periode 2003-2006. http://www.deptan.go.id [30 Mei 2009].

Djoko Isbandi, 1986. Fisiologi Pertumbuhan dan Perkembangan Tanaman.. Faperta UGM. Yogyakarta.257 hal.

Hakim, N, M. Y.Nyakpa, A. M.Lubis, S.G. Nugroho, M.R. Saul, M.A. Diha, Goban Ban Hong dan H. H. Bailay. 1988. Dasar-Dasar Ilmu Tanah, Universitas Lampung.

Hardjowigeno, S. 1995. Ilmu Tanah. Akademika pressindo.Jakarta

Haryatini, B.A. dan Muji Santoso 2001. Pertumbuhan dan Hasil Cabai Merah (Capsicum Annuum)pada Andisol yang DiberiMikrorza, Pupuk Fosfor dan Zat Pengatur Tumbuh. Biosain. 3:50-7.
IIED - International Institute for Environment and Development, 2002. Potash Case Study.InformationSupplied by the InternationalFertilizer IndustryAssociation.Http://www .iied.org./mmsd/mmsd_pdfs/obs _ifa.pdf.

Kaunang, C.L., 2004. Respons Ruminan Terhadap Pemberian Hijauan Pakan Yang Dipupuk Air Belerang.Disertasi. Sekolah Pascasarjana Institut Pertanian Bogor, Bogor.

Marschner, H. 1995. Mineral Nutrition of Higher Plants. Academic Press, NewYork

McKenzie, R. 2001. Potassium Fertilizer Application in Crop Production.Http://www.agric.go v.ab.ca/ universalpages/includes/docheader.map

Perrenoud, S, 1993. Potato.Fertilisers for Yield and Quality.International Potash Institute, Berne/Switzerland.IPI Bull. No.8.

Robson, A.D. and M.G. Pitman, 1983.Interaction between nutrient in higher plants. Encyclopedia of Plant Physiology. 154: 147 - 180.

Sudjoko Sahat dan Hendro Sunaryono, 1995.Varietas Kentang dan Pemeliharaannya.Lembang. Jawa Barat. 187 hal.

Sumardi dan Suriatna, 1993. Pupuk dan pemupukan. Metro Putra. Jakarta. 96 hal.

Schnug, E. 1990.Sulphur nutrition and quality of vegetable.Sulphur in Agr. 14: 3-6. 